\title{
IMPLEMENTATION OF ISSUANCE OF BIRTHDATES OF CHILDREN OUT OF MARRIED AS CIVIL RIGHTS IN THE DEPARTMENT OF POPULATION AND CIVIL REGISTRATION OF MEDAN CITY
}

\author{
Maria Rosalina, Nur Aisyah Fitri \\ Faculty of Law, Islamic University of North Sumatra \\ maria.rosalina@fh.uisu.ac.id
}

\begin{abstract}
Inclusion of the names of both parents in the child's birth certificate can only be done if the child is born from a marriage which is carried out under religious law and state law, as stipulated in Article 2 Paragraph (1) and (2) of the Marriage Law. Article 27 Paragraph (1) and (2) of the Child Protection Law states that the identity of each child must be given from the time the child is born, which is stated on the birth certificate. The phrase must, which is contained in the sentence of each child's identity must given from birth in Article 27 Paragraph (1) of the Child Protection Law, it means that to have a birth certificate for a child is a must, regardless of whether the child is a legal child or a child born from an illegal marriage, in other words an outside child. Marry. The Method use in this research is empirical legal research. The purpose of this study was to determine the requirements and procedures for the issuance of birth certificates for legal and out-of-wedlock children as civil rights. In the Medan City Population and Civil Registry Service, the obstacles faced and overcome these obstacles. In theory, this research is useful for literature in the field of civil law, especially the civil rights of children on the Child Birth Certificate Issuance Implementation Beyond Marriage For Civil Rights in the Department of Population and Civil Registration Medan. City practically contribute ideas to parents whose marriage has not been registered, and practitioners law regarding the procedure for making birth certificates for children outside of marriage. This research is descriptive analysis. The type of research used is juridical normative and juridical empirical, with primary and secondary data, namely 1 (one) population officer, 1 (one) birth certificate officer and as an informant is the Head of the Medan City Population and Civil Registration Service.
\end{abstract}

Keywords: Birth Certificates, Excluding Married, Children..

Journal History

Received August 27, 2020;

Reviewed October 09, 2020;

Accepted October 28, 2020;

Published November 1, 2020

Copyright@2020 NLR. All right reserved. 


\section{INTRODUCTION}

Article 1 of Law No.1 of 1974 concerning Marriage (hereinafter referred to as the Marriage Law) states that marriage is: "The inner and outer bond between a man and a woman as husband and wife with the aim of forming a happy and eternal family (household) based on the Supreme Lordship. One." Whether there is a right of the wife or the children born in the marriage, should the evidence, the legal marriage according to the religion and according to the country between wife and husband. ${ }^{1}$

The state as the ruler is obliged to provide protection for children's rights, since the child is born. One example of child protection, which is also a civil right for children, is having a birth certificate. ${ }^{2}$ Child's birth certificate can be used as an identity or a tool to prove the child's identity, because the child's birth certificate clearly states the day, place, date, month and year of birth and affirms or includes the name of the parent who gave birth to it. Inclusion of the names of both parents in the child's birth certificate can only be done if the child is born from a marriage that is legally valid under religious law and state law, as mentioned in Article 2 Paragraph (1) and (2) of the Marriage Law, in essence it states that a

1 Shedharyo Soimin, Hukum Orang dan Keluarga, (Jakarta: Sinar Grafika, 2004), p. 31.

2 Maria Rosalina, Sosialisasi Aspek Hukum Akta Kelahiran Sebagai marriage is legal if it is carried out according to the law of religion and belief of each and the marriage is recorded according to the prevailing laws and regulations.

Furthermore, Article 43 Paragraph (1) of the Marriage Law states: "Children born outside of marriage only have a civil relationship with their mother and their mother's family". Thus, in making birth certificates for children born outside of marriage as stated in Article 2 Paragraph (1) and (2) of the Marriage Law, based on Article 43 Paragraph (1) of the Marriage Law, only the name of the child's mother is stated, without any inclusion. father's name. However, the editorial staff of Article 43 Paragraph (1) of the Marriage Law underwent a change after a judicial review was conducted at the Constitutional Court, with case Number 46 / PUUVIII / 2010. Based on the decision of the panel of judges of the Constitutional Court Number 46 / PUU-VIII / 2010, dated February 13, 2012, which was pronounced in the plenary session of the Constitutional Court open to the public on February 17, 2012, the editorial staff of Article 43 Paragraph (1) of the Marriage Law must be read as follows: Children born out of wedlock have a civil relationship with their mother and their mother's family as well as with men as their father, which can be

Hak Perdata Bagi Anak LuarKawin, Laporan Kegiatan Pengabdian Kepada Masyarakat, Fakultas Hukum, Universitas Islam Sumatera Utara, 2019, p. 3. 
proven based on science and technology and / or other evidence by law to have blood relations, including civil relations with their father's family. $^{3}$

Based on the decision of the Constitutional Court Number 46 / PUU-VIII / 2010, then children born outside of marriage are legitimate, as long as it can be proven by science and technology and / or other evidence according to the law, have blood ties and civil, the father and the father's family, so in making the child's birth certificate, the names of both parents can be included, namely the names of the mother and father. ${ }^{4}$ The principle of equality which is the basis of thought in the Decision of the Constitutional Court Number 46 / PUU-VIII / 2010 is in accordance with the principle of masalihu al-'am (general benefit) which protects the souls of children (hifdzu al-nafs) as the next generation of human life (hifdzu al-nasl). ${ }^{5}$ Apart from that, to issue birth certificates for children whose origins or whereabouts of parents are not known also have certain requirements, as contained in Article 33 Paragraph (3) of Presidential Regulation Number 96 of 2018 concerning Requirements and Procedures for Population Registration And Civil Registration (hereinafter referred to as Perpres

${ }^{3}$ Constitutional Court Decision Number 46/ PUU-VIII/2010, p.37

${ }^{4}$ Maria Rosalina,Op.Cit. p 3-5.

${ }^{5}$ Bahruddin Muhammad, Akibat

Hukum Putusan Mahkamah Konstitusi Nomor 46/PUU-VIII/ 2010 Terhadap
No.96 of 2018), while the agency in charge of carrying out the registration and issuance of birth certificate quotations is the civil registry office, especially the Medan City Civil Registry Office.

Based on the above background, it encourages researchers to conduct research on the problem of what are the requirements and procedures for issuing birth certificates for legal and out-ofwedlock children as civil rights at the Medan City Population and Civil Registry Service, what are the obstacles faced in issuing birth certificates for children outside of marriage that are is the civil rights of children in the Population and Civil Registry Office of Medan City and how to overcome these obstacles, which are summarized in a research title Implementation of the Issuance of Birth Certificates of Children Outside of Marriage as Civil Rights at the Population and Civil Registry Office of Medan City.

The purpose of this research is to know the requirements and procedures for the issuance of birth certificates legitimate child and a child outside of mating as civil rights in the Department demography late and Civil Medan, knowing the obstacles encountered in the issuance of birth certificates of children outside of mating, and to know the effort

Pembagian Hak Waris Anak Luar Perkawinan, Article, Mahkamah Agung Republik Indonesia, Direktorat Jenderal Badan Peradilan Agama, published on 17 Desember (2013). 
overcoming obstacles faced in issuing birth certificates for children outside of marriage at the Medan City Population and Civil Registry Office. The theoretical benefit of this research is that the results of this study can be used as literature in the field of law, especially civil law and children's civil rights regarding the implementation of the issuance of birth certificates for children outside of marriage as a civil right in the Department of Population and Civil Registry of Medan City, and practically give contribution of thoughts to people. parents who marry and have not been registered according to the applicable laws and regulations, and legal practitioners regarding the procedure for making birth certificates for children outside of marriage, which is a child's civil right .

\section{METHOD}

The research method is o bjek in research that is Implementation of Child Birth Certificate Issuance Outside Marriage For Civil Rights at the Department of demography and Civil Medan. The location of this research was conducted at the Department of Population and Civil Registration of Medan City, Jalan Iskandar Muda Medan, North Sumatra. The nature of the research used will be descriptive, with juridical

normative and empirical

juridical research types. The

data used are primary data, obtained from interviews with

respondents, namely 1 (one) population officer, 1 (one) birth certificate officer and 1 (one) informant, namely the Head of the Medan City Population and Civil Registration Service. secondary data consists of primary law material, such as the child's birth certificate is legitimate and children outside mating, the Civil Code, Marriage Law, law Number 24 Year 2013 on the Amendment to law Number 23 Year 2006 concerning Population Administration, Presidential Decree No. 121983 About Setting and Improved Implementation Development of Civil, Presidential Regulation No. 96 year 2018 About the Requirements and Procedures for Registration of Population and Civil Registration, secondary law material, and tertiary such as internet media, kam us, encyclopedia. Data analysis was carried out on primary and secondary data obtained in this study, using qualitative analysis.

\section{DISCUSSION}

\section{Profile of the Department of Population and Civil Registration of Medan City}

In the Decree of the Mayor of Medan Number 01 of 2017 concerning Position, Organizational Structure, Duties and Functions, and Work Procedures of Regional Apparatus, the Medan City Population and Civil Registry Service is a supporting element of the Medan City government led by a head of service who is under and responsible answer to the mayor through the regional secretary. The Medan City Population and Civil Registry Office having its address at 
Jalan Iskandar Muda Number 270, Petisah Tengah, Medan Petisah District, Medan City, North Sumatra 20151, is an element that executes government affairs in the field

of population administration and civil registration, and has the task of helping the Mayor of Medan carry out his affairs. regional government in the field of population administration and civil registration based on the principles of autonomy and assistance tasks.

\section{Requirements and Procedures for Issuance of Birth Certificates of Legitimate Children and Children Outside of Marriage as Civil Rights at the Population and Civil Registry Office of Medan City}

There are three reasons why birth registration is important, namely as follows:

1. Birth registration is a formal recognition of the existence of a child, individually against the state in law.

2. Birth registration is an essential element of national planning.

3. Birth registration is a way to secure children's rights, for example identification of children after fighting, neglected or kidnapped, so that children can know their parents (especially if they were born out of wedlock), so that they have access to facilities or infrastructure under state protection within the age limit.

6 Victor M. Situmorang,Aspek Hukum Akte Catatan Sipil di Indonesia, Sinar Grafika, Jakarta, 1991,p. 2. laws such as employment, and in juvenile justice systems and reduce or the possibility of selling babies or infanticide. ${ }^{6}$ The registration of a child's birth is realized by making a birth certificate for the child .

If a citizen of Indonesia want to register the birth of their children, based on Article 33 Paragraph (1) Perpres No.96 of 2018, must meet the requirements, which include:

a) Certificate of birth;

b) Marriage book / marriage certificate quotation or other valid evidence;

c) Family card and

d) e -KTP.

The purpose of Article 33 Paragraph (1) Perpres No.96 of 2018 , is for the registration of the child's birth, in the event that the child is born from a legal marriage, it must meet the requirements, including a birth certificate, for example a birth certificate from a person or midwife who helps the child's birth, a marriage book or excerpt from marriage certificate or other valid evidence, family card and electronic identity card. Furthermore, in Paragraph (2), it is stated that the birth registration of Indonesian citizens, for children who have just been born or have just been found and whose origin or whereabouts of their parents are not known, must meet the requirements of the official report from the police. Article 33 Paragraph (2) Perpres No. 96 of 2018 means that children who have Indonesian 
citizens, who have just been born, are found and have no known origin or whereabouts of their parents, if the child's birth is to be registered then the conditions are that other than those stated in Article 33 Paragraph (1) above must also be there is an official report from the police where the child was found. Then in Paragraph (3), it is necessary to register the birth of Indonesian citizens for children whose origins or whereabouts of their parents are not known, other than those referred to in Paragraph (2), must fulfill the requirements of a statement letter of absolute responsibility for the accuracy of birth data with 2 (two) witnesses. . Thus according to Article 33 Paragraph (3), for a child whose origins or whereabouts are not known and the parent is not found, then if the child's birth will be registered to obtain his / her birth certificate, the conditions are other than those stated in Article 33 Paragraph (1) Perpres No. 96 2018 , which is a certificate of birth, marriage certificate / quote a marriage certificate or other evidence of legal, family card and ID card-el, also must meet the requirements of the other is to make a statement of absolute liability on accuracy of data on child birth are the two (2) a witness. Furthermore, Article 33

Paragraph (4) of birth registration, for children of Indonesian citizens who live outside the territory of the Republic of Indonesia and are visiting Indonesia must meet the requirements, namely a birth certificate, marriage certificate / marriage certificate quote or other proof of marriage / marriage, parents record document, such as passport and visa or $\mathrm{s}$ uric information to move overseas. In this document the family card and ID-el did not give more because these two documents have been met through a marriage certificate or marriage certificate quotation and travel documents from child parents. Pursuant to Article 33 Paragraph (1), (2), (3), (4) and (5) Perpres No. 96 of 2018, both Indonesian citizens and Singapore citizens, can register the birth of their child in Indonesia to obtain a child's birth certificate as the child's identity and civil rights.

Management of birth certificates at the Population Office of the City of Medan is divided into 2 (two) parts for a birth certificate application, namely based on the age of birth from 0 to 60 days of age and 60 days of age and above. The resident who is obliged to report the birth is the head of the family, one individual declares one identity. In the book of the Medan City Population and Civil Registry Service, it is stated that the completeness of the requirements for making a child's birth certificate based on the age of birth is as follows: a) The age of children $0 \mathrm{~s} / \mathrm{d} 60$ days, namely: family card, Identity husband and wife card, s veins childbirth (midwife / hospital / clinics / health centers), buku marriage (Muslim) / deed records Civil (non Muslim), 2 (two) witnesses and their Identity Cards, for those who authorize or represent the birth certificate management to another 
person, attach a power of attorney.

b) Age 60 days and over, namely family card, husband and wife Identity Card, child birth certificate (midwife / hospital / clinic / mini hospital), marriage certificate (Muslim) / Civil Registry certificate (non-Muslim), 2 ( two) witnesses and inhabitants Identity Card, s veins from the urban village and attach power of attorney for the proxy, attach diploma elementary, junior high, high school, those who already have a diploma, s veins statement chronological list of children. Terms maintenance of the birth certificate an ak is done based on the principle of domicile. For those who do not have a birth certificate, it can be replaced with a certificate or report card. If you do not have a diploma, you must attach a stamped statement that does not have a certificate. Furthermore, if you do not have a marriage certificate or a certificate of civil registration, and were born after 1974, should attach a letter of statement of a mother's son sealed, so the birth on deed as the child of a mother. ${ }^{7}$

Registration of child births carried out by parties who need them at the Medan City Population and Civil Registry Office, when viewed from the implementation

${ }^{7}$ Department of Population and Civil Registration of Medan City, Dokumentasi ISO 9001:2008, SistemManajemen Mutu, Pemerintah Kota Medan, 01 September 2014, p.268. $8 \quad$ AG.Subarsono, Analisis Kebijakan Publik, (Yogyakarta: Pustaka Pelajar, 2011), p.93. theory of policy content ( content of policy put forward by Merilee S. Grindle, ${ }^{8}$ and associated with human rights theory, namely the theory of positivism (positivist theory) $)^{9}$ is already running and precise and mutual support. From theory of positivism (positivist theory) is that the content of the right, is a human right, in this case the child rights is legitimate, and children beyond mating to get his or her identity in the form of a birth certificate, which is a civil rights of children, can only be derived from state law. The state law in question is regulated in legislation such as the Child

Protection Law, Presidential Decree No. 96 of 2018, the Population Administration Law, the Marriage Law, Presidential Decree No. 12 of 1983 and others. Based on the content of the policy (content of policy), the rights regulated in this country's law, namely the registration and issuance of birth certificates for children, which are civil rights as well as human rights for both legitimate and unmarried children to obtain their identity through birth certificates can be implemented based on regulations. who set it up. In terms of the implementation environment ( context of implementation $I$, that state laws such as the Child

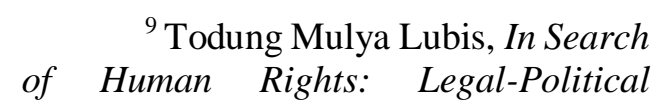
Dilemmas of Indonesia's New Order,1966-1990, (Jakarta: Gramedia Pustaka Utama, 1993), p.14 - 25. 
Protection Law, Presidential Decree No. 96 of 2018, the Population Administration Law, the Marriage Law, the Presidential Decree No.12 of 1983, are drafted and implemented to guarantee and protect children's rights in Indonesia , both legitimate children and non-married children to obtain their identity through a birth certificate Besides that, the parents can also administer or register the birth certificate of a foreign child in Indonesia.

Based on the results of interviews conducted on Monday, June 29, 2020 by the head of a birth certificate, procedures and mechanisms for creating the child's birth certificate is legitimate, is to be fill form, then follow the steps that have been determined attach the terms of publishing or making of $n$ birth certificate which includes the identity card of the parents, family card, birth certificate from the hospital or midwife, marriage certificate or marriage certificate, and the identity card of the witness. Meanwhile, the procedure and mechanism for making birth certificates for out- ofwedlock children, whose parents do not have a marriage book or marriage certificate or other valid evidence, but the relationship status on the family card shows that they are husband and wife, because their marriage has not been recorded in accordance with applicable laws and regulations, or

${ }^{10}$ Interview with the Head of the Birth Certificate of the Medan City Population and Civil Registry Office, Shita, 29 Juni 2020. not having a birth certificate is also the same as the procedure and mechanism for making a birth certificate for a legitimate child, it's just that the requirements for the Absolute Responsibility Statement (SPTJM) for husband and wife, and SPTJM for the correctness of birth data (vide Article 34 letters (a) and (b) of the Presidential Decree No.96 of 2018$))^{10}$ Following is picture 1: SPTJM sheet of truth as husband and wife .

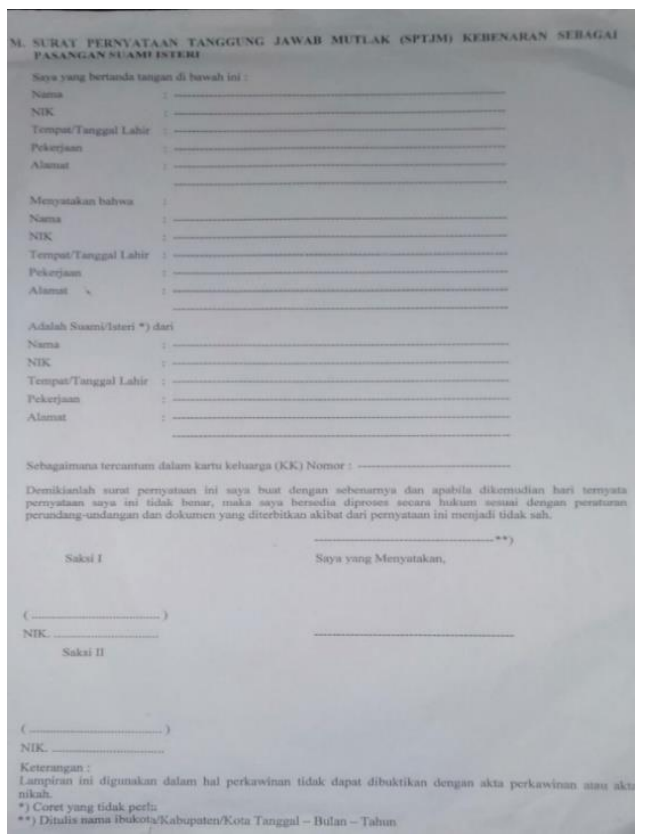




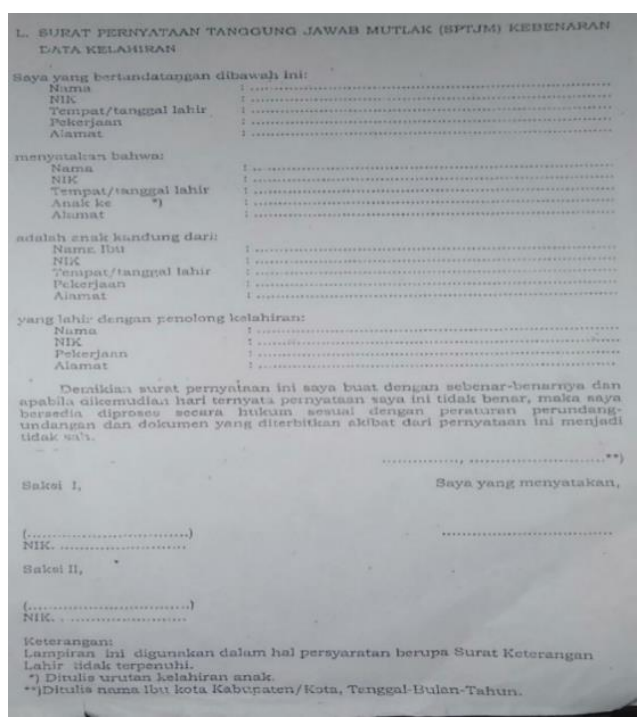

Figure 2: SPTJM sheet of correctness of birth data

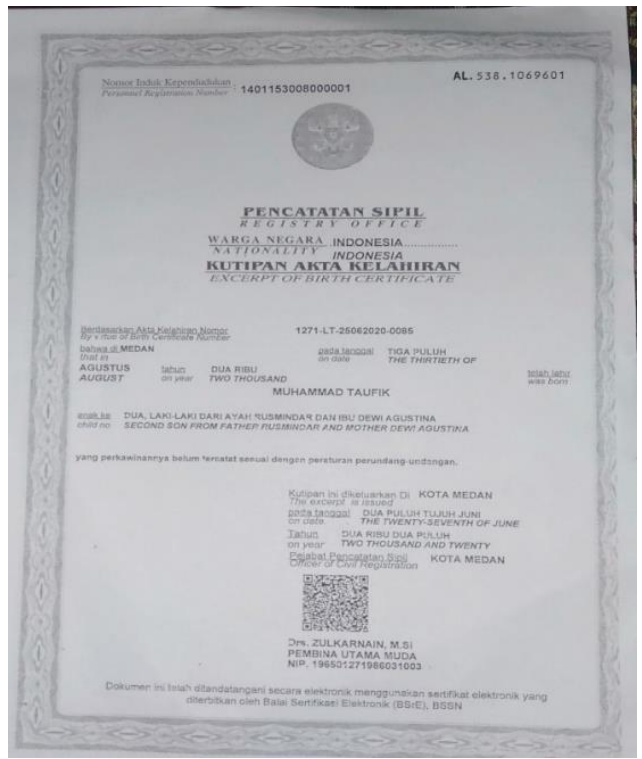

Example 3: Birth certificate of a child, whose parent's marriage has not been recorded

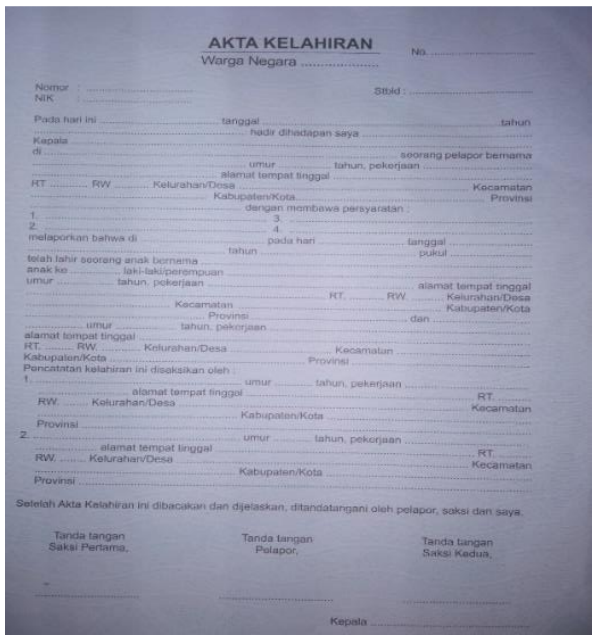

Example 4: Minutes of making a birth certificate

Based on figures 1 and 2 above, even though the marriage has not been registered at the Medan City Population and Civil Registry Service, it cannot be proven that the marriage of the child's parents with a marriage certificate or marriage certificate, writing or inclusion of the name of the male parent (father) The child in the manufacture of permanent birth certificate may be made, as long as their attachment SPTJM truth as the couple of parents of children outside the mating. Child's birth certificate both legitimate child or children outside of mating, in writing within two (2) language that is the language Indonesia and the United Kingdom, and the back of the child's birth certificate contained the minutes of the birth certificate, as shown in Figure 4 at the top. Furthermore, the procedures of child's birth certificate outside of mating parents her or her father unknown or do not want to admit it, is the same as the procedures of child's birth certificate valid at plus enclosed a n a statement from her 
parents (mother) of the child, stamped Rp. 6000, - as in Figure 5 below.

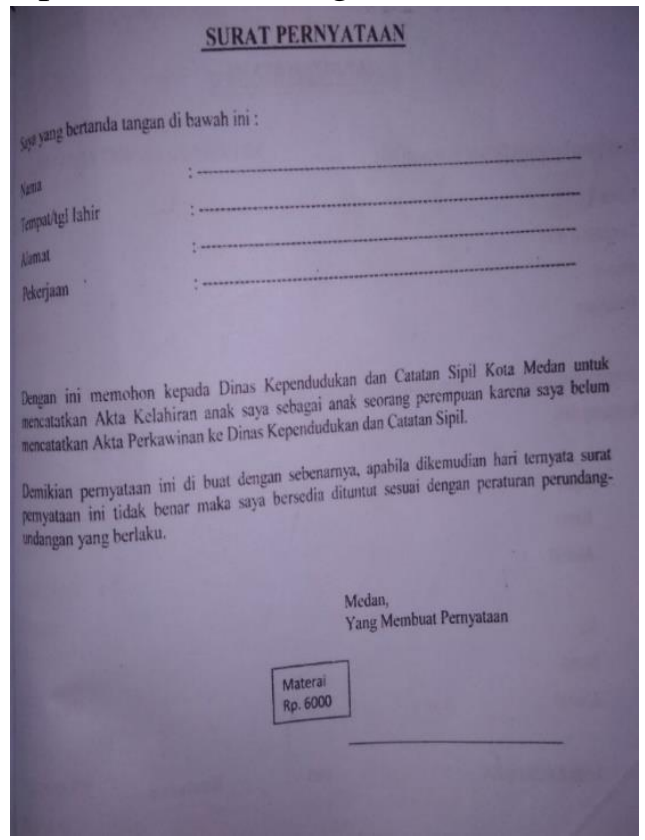

An example of a child's birth certificate, which only includes the name of the woman's parent (mother) can be seen in Figure 6 below.

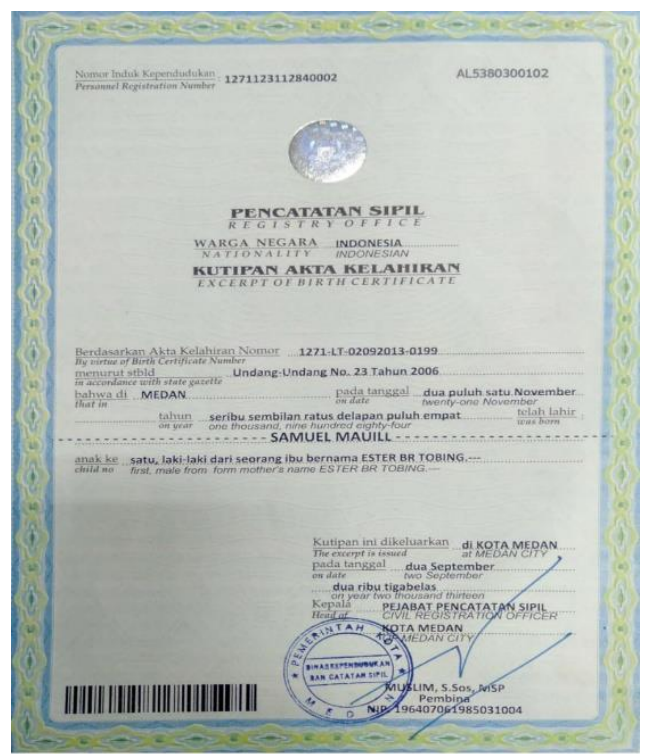

The following is picture 7 below: The birth certificate of the child is valid

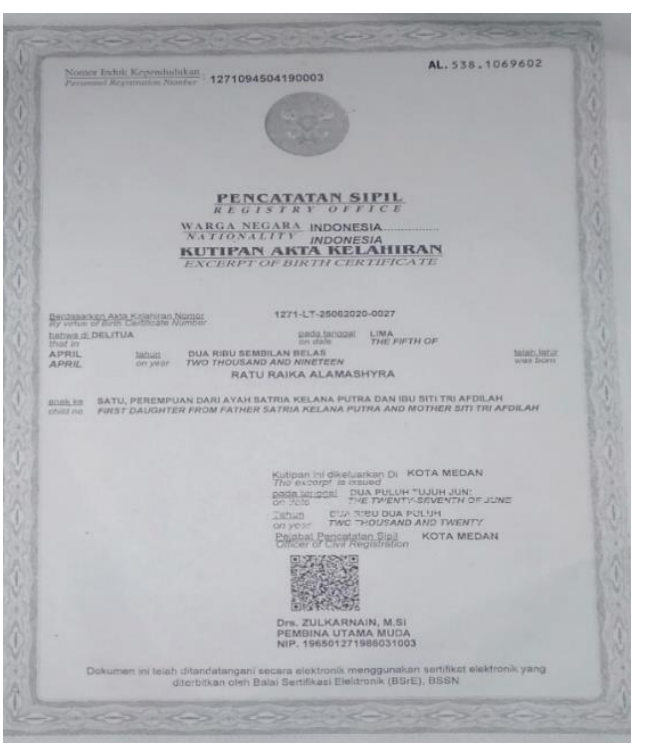

On the birth certificate of this legal child, the names of both parents are included. In connection with the rights of children outside of marriage who include the name of their male parents (father) on their birth certificates, the researcher asked the respondent to the Head of the Birth Certificate of the Medan City Population and Civil Registry Office, whether it had something to do with the Constitutional Court decision Number 46 / PUU-VIII / 2010 concerning the Material Review of Article 43 Paragraph (1) of the Marriage Law, and the respondent answered that there was no connection, because the inclusion of the name of the male parent (father) of the child outside of marriage on his birth certificate is regulated in statutory regulations such as Presidential Regulation No. . 96 of 2018, by attaching the SPTJM of truth as husband and wife, a statement letter for a mother's child from a woman's parent (mother). The material test is only 
related to explain and determine the position of the child of the material test applicant as the heir of the material test applicant and the husband of the material test applicant. ${ }^{11}$

Based on the above and from Figure 1 through Figure 7 , it turns issuance of birth certificates of children outside of mating as civil rights in the Department of Population and note the late Civil Medan has performed in line with the theory of implementation by Merilee S. Grindle influenced by two (2) the large variables, namely the content of policy and the second environment of implementation (context of implementation), where this implementation theory in its implementation is also linked to the human rights theory, namely the positivism theory ( positivist theory) as outlined in state legislation.

Obstacles Faced in the Issuance of Birth Certificates of Children Outside of Marriage which are the Civil Rights of Children in the Department of Population and Civil Registry of Medan City and Efforts to Overcome Obstacles .

Based on the results of interviews with respondents, the Department of Population and Civil Registration of Medan City, in carrying out its duties, in recording and making birth certificates for

${ }^{11}$ Interview with the Head of the Birth Certificate of the Medan City Population and Civil Registry Office, Shita, 29 Juni 2020. children, especially children outside of marriage, have no obstacles, because if there are obstacles, they are resolved by applicable mechanisms and procedures, according to with legislation. The human resources in the Office of Population and Civil Registry of Medan City are adequate and have been working in accordance with their respective fields. Services for making birth certificates have implemented the operational service standards applicable at the Medan City Population and Civil Registry Office. The procedures and procedures for making child birth certificates already have a flow and terms and conditions based on Presidential Decree No.96 of 2018. ${ }^{12}$ However, based on the results of interviews with people who administer birth certificates at the Medan City Population and Civil Registry Office, there are several obstacles, including:

a. Lack of public awareness about the importance and use of birth certificates as a child's identity, for the fulfillment of children's civil rights, so that people often do not immediately take care of their child's birth certificate. The community just takes care of their child's birth certificate, if needed, for example to go to school, to apply for a job and so on.

${ }^{12}$ Interview with the Head of the Birth Certificate of the Medan City Population and Civil Registry Office, Shita, 29 Juni 2020. 
b. For children born outside of a legal marriage, parents, especially mothers of children outside the marriage, often feel ashamed that they do not take care of their child's birth certificate.

c. There is a lack of understanding and negative views from the community that obtaining birth certificates for children, especially for children outside of wedlock, requires a complicated procedure, takes a long time and requires a lot of money.

If it is related to implementation theory according to Merilee S. Grindle which is influenced by 2 (two) major variables, namely the content of policy and the two implementation environments (context of implementation ), which in practice is linked to the human rights theory, namely positivism theory. (positivist theory) regarding state laws and regulations, the obstacle felt by the community in processing the birth certificate of children outside of marriage is something that is always found in the application or implementation of a statutory regulation. In implementing a regulation it does not always work smooth, obstacles can come from members of the community themselves, for example, whether the community has difficulty understanding the laws and regulations, is lazy or wants a quick way to get what they want, lacks awareness and willingness and does not comply with existing regulations and so on. Barriers from service providers, in this case the Department of Population and Paint Civilians, although based on the results of interviews with respondents it is stated that there is no, but based on the observations of researchers and interviews with community members, the obstacles that arise are about the untimely issuance of birth certificates, and the long bureaucracy, especially during the Covid 19 era. .

Efforts to

overcome obstacles regarding the cost of registration and issuance of expensive birth certificat es for children, it is better if the application for the issuance of a child's birth certificate is made from the age of 1 (one) to 60 (sixty) days from birth because there is no fee at all. Proposals for late birth certificates levy fines of delay as much as 10,000, - (ten thousand rupiah). Against the negative view of the people who say that to take care of child's birth certificate, especially children outside of mating requires procedures cumbersome, and time consuming la ma, Office of Population and Civil Registration Medan, found the Department of Population and Civil Registry already operating with the network system Internet on line with links throughout Indonesia, so that there will be no more difficulties in accessing information on the requirements and procedures for making a birth certificate. In addition, the flow or process for recording and issuing a child's birth certificate only takes 4 
( four) days and can be seen on the information board provided by the Education Office and the City Civil Registry. Regarding the lack of public awareness of the importance and use of a birth certificate as a child's identity, for the fulfillment of a child's civil rights, the Medan City Population and Civil Registry Office has conducted socialization and outreach to the community about the need for a birth certificate for a child, made banners for making a certificate. free births, in collaboration with related agencies such as urban village offices, village offices and courts to pick up the ball in making child birth certificates.

In connection with the issuance of this birth certificate, the Office of Population and Civil Registration of Medan City, during the last 2 (two) years, namely from 2018 to 2020, has issued 121,641 (one hundred twenty one thousand six hundred and forty one ) birth certificates of children. legal, and for birth certificates of children outside of marriage, the number of birth certificates is 30,300 (thirty thousand three hundred). ${ }^{13}$

\section{CONCLUSION}

As a conclusion in this study, the requirements and procedures for issuing birth certificates for legal children and children outside of marriage as civil rights for children are carried out in accordance with the applicable laws and regulations. The existing obstacles,

\footnotetext{
${ }^{13}$ Interview with the Head of the Birth Certificate of the Medan City
}

based on the results of the interview, there were differences of opinion between the Medan City Population and Civil Registry Office which said there were no obstacles, while according to the community there were several obstacles.

Advice, should $\mathrm{p}$ he

Government further facilitate more services da lam registration and issuance of birth certificates of children, especially outside of mating, so that the civil rights of children outside of mating to have a birth certificate can be met and he kui position in front Law. Government fixed policy to not levy costs in recording and issuing a child's birth certificate. The Department of Population and Civil Registry of Medan City should further improve socialization and legal counseling to the public regarding birth certificates for children outside of wedlock, continue to increase cooperation between agencies and pick up related balls regarding the registration and issuance of birth certificates for children, especially the birth certificates for children outside of marriage.

\section{REFERENCES}

Constitutional Court Decision
Number 46/ PUU-VIII/2010.
Department of Population and Civil
Registration of Medan City,
Dokumentasi ISO 9001:2008,
Sistem Manajemen Mutu,

Population and Civil Registry Office, Shita, 29 Juni 2020. 
Pemerintah Kota Medan, 01

September (2014).

Interview with the Head of the Birth

Certificate of the Medan City

Population and Civil Registry

Office, Shita, 29 Juni 2020.

Lubis, Todung Mulya. In Search of

Human Rights: Legal-

Political Dilemmas of

Indonesia's New Order,1966-

1990, Jakarta: Gramedia

Pustaka Utama, 1993.

M. Situmorang, Victor. Aspek

Hukum Akte Catatan Sipil di

Indonesia, Sinar Grafika, Jakarta, 1991.

Muhammad, Bahruddin .Akibat Hukum Putusan Mahkamah Konstitusi Nomor 46/PUUVIII/ $2010 \quad$ Terhadap Pembagian Hak Waris Anak Luar Perkawinan, Article, Mahkamah Agung Republik Indonesia, Direktorat Jenderal Badan Peradilan Agama, published on 17 Desember (2013).

Rosalina, Maria. Sosialisasi Aspek Hukum Akta Kelahiran Sebagai Hak Perdata Bagi Anak LuarKawin, Laporan Kegiatan Pengabdian Kepada Masyarakat, Fakultas Hukum, Universitas Islam Sumatera Utara, (2019).

Soimin, Shedharyo. Hukum Orang dan Keluarga, Jakarta: Sinar Grafika, 2004.

Subarsono, AG. Analisis Kebijakan Publik, Yogyakarta: Pustaka Pelajar, 2011. 